\title{
English Education in Distress?
}

\author{
HEATHER EGGINS
}

Heather Eggins is visiting professor at the University of Sussex, UK. E-mail: heggins@btinternet.com.

England, like every Western country, is concerned to maximize the abilities of its people and thereby, through their skills, enrich the nation. Hence, over the last 10 years, the issue of access to higher education has been of great concern to the English government but is now, in combination with changes in circumstance, facing considerable problems. The efforts of the last government, a Labour administration, met with some success, in that the participation rate for those from disadvantaged groups that stood at 18 percent in 2004 is now much improved. A range of initiatives was introduced, including summer schools, mentoring, visits to local universities, and specially designed "access" courses. Now, however, with the participation rate of those groups standing at 30 percent, the universities are caught in a whirl of confusing and conflicting policies that threaten to undermine the success of the access drive and destabilize the whole system.

\section{The Present Government's ApProach}

The present Conservative Liberal Democrat coalition, elected in 2010, has had to govern in an era where tough financial measures need to be introduced in response to the international crisis. Up to $£ 9,000$ per year can now be charged in 
tuition fees, and students have considerably more "buying power." Students now have a very wide range of bursary offers by individual universities to consider, and if they are fortunate enough to gain two A marks and a B mark, they can expect to get a place at the university and course of their choice. The fact that students who gain the highest grades can go anywhere they choose means that the universities have an inability to plan their final figures. A level of uncontrollable risk has been introduced, which is causing great financial distress for them, with a number of universities in deficit.

\section{FAIR ACCESS}

The notion of "widening participation" implies attracting more overall numbers of students and expanding the total system. The notion of "fair access" makes it possible for all those from disadvantaged backgrounds who have the ability to attend university. A recent government report makes recommendations for a new, national access strategy. A network of regional coordinators will be created to target primary schools and work with pupils through their secondary school and sixth-form studies. The aim of the network is to support bright children from primary school age, whatever their background, to aspire to attend university and to make sure they are academically prepared for it.

The Office for Fair Access, a government body, has the role of approving the access policies of every higher education institution that intends to charge over $£ 6,000$ tuition fees annually. Institutional access policies are expected to include a range of bursaries, as well as other access initiatives. The most elite universities, which have historically had higher percentages of students from 
independent schools, are under pressure to accept more pupils from disadvantaged backgrounds.

However, against this background of the ongoing policy on access, the financial crisis remains and, in England, there is a $£ 9,000$ maximum tuition fee for undergraduate studies. The burden of paying has shifted from direct government funding to institutions to loans made by the government for the student to cover the cost. These are available to full and part-time students and to students studying at private universities. Means-tested grants for accommodation costs are still available for those from disadvantaged backgrounds.

\section{Allocated Target Numbers}

A major problem in the English system is the way in which the overall numbers are controlled. Each university has an allocated target, proposed by the Funding Council. There is little leeway in failing to meet the target, or overstepping the target, before there is a lowering of the allocated number allowed or a fine imposed for overstepping. This system, though tricky to manage, worked reasonably well. However, in an effort to open up the system to more student choice, the whole system has become unstable.

\section{Problems}

Two initiatives in particular have caused this. The first has been concerned with the range of fees charged by universities. In order to make sure that students were offered a range of prices for higher education places, the government made 
20,000 places available in 2012 to institutions charging $£ 7,500$ or less. These places were meant to act as an incentive to universities to drop their prices to $£ 7,500$ or less and to colleges to offer courses at degree level and thereby draw in more money from government. However, the incentives did not work. Of the 9,600 places allocated to universities, 4,200 were unfilled, and of the 10,400 allocated to Further Education colleges, 2,800 were left empty (i.e., over a third were unused).

The second initiative has formed more serious effects, creating uncertainty and, for institutions, a high level of risk. In 2012, the government allowed universities in England to recruit as many extra students as they wished-with the grades $\mathrm{AAB}$ (the highest grades)—in the university entry examinations. This appeared to be advantageous to the universities in the most-highly selective group (the Russell Group). However, the overall numbers of applicants for 2012/13 showed a fall of 5 percent for those aged 18 and a fall of 15-20 percent for those aged 19 and older. The pool of those applicants achieving AAB shrank, which left several universities unable to enroll the numbers of students they expected. Liverpool, Sheffield, and Southampton-all in the Russell Groupfailed to meet their targets, though the University of Bristol grew by 28 percent. Among those other universities charging less than the full $£ 9,000$, there were wide variations. While Staffordshire University showed a loss of only 3 percent, Leeds Metropolitan was down 23 percent.

\section{3/14}

The 2013/14 arrangements could well introduce even more fluidity into the English system: This time, students with $\mathrm{ABB}$, a larger pool than $\mathrm{AAB}$, can be 
offered places at any university. The rules for the extra places at the margin are also changed: There will be only 5,000 places, but many of these will go to institutions charging between $£ 7,500$ and $£ 8,250$ a year.

Meanwhile each university continues to be allocated a fixed intake of students. Eleven higher education institutions exceeded their limits on student numbers in 2012; the fines have just been published. Take too many students, and you are fined. Take too few and your numbers for the future risk being cut. It is a tightrope that few would voluntarily choose to walk. The applications for 2013/14 in England are marginally up $(+2.8 \%)$ on 2012/13, but still a good deal below 2011/12. The volatility could well be worse next year. The combination of sudden changes of policy, against a background of a hike in tuition fees that students were unprepared for, has destabilized the English higher education system: A growing number of English universities will be faced with deficits. The outcomes in 2013/14 could spell unacceptable financial turmoil for them. "The students," as the Minister for Higher Education says, are now "in the driving seat"; the institutions are in retreat. 